\title{
PERAN PERAWAT DALAM MENERAPKAN TAHAPAN PENGKAJIAN PROSES KEPERAWATAN BERBASIS SPIRITUAL
}

\author{
Muhaini Atmayana Purba / 181101131 \\ muhainipurba1@gmail.com
}

\begin{abstract}
ABSTRAK
Latar Belakang : Proses keperawatan tidak terlepas dari peran perawat dalam menjalankan tugas dan tanggung jawabnya dalam memberikan layanan kesehatan kepada pasien. Salah satunya adalah melaksanakan pengkajian. Hal ini menjadi penting karena pengkajian dalam proses keperawatan merupakan dokumen yang mencatat tindakan yang dilakukan oleh perawat terhadap pasien. Tujuan : Untuk mengidentifikasi langkah awal dalam membuat suatu pengkajian, diagnosa keperawatan, rencana asuhan keperawatan, implementasi, evaluasi, dokumentasi asuhan keperawatan secara spiritual. Metode : metode yang digunakan merupakan literatur review atau suatu perbandingan atau analisis antara satu jurnal dengan jurnal lainnya dari berbagai sumber seperti referensi jurnal, buku teks dan e-book. Hasil : Adapun hasilnya adalah seorang perawat mampu melaksanakan tahapan pengkajian dalam proses keperawatan baik secara spiritual dengan tepat sesuai dengan standar operasional prosedur dan data yang didapati oleh perawat. Kesimpulan : Sebagai seorang perawat sangatlah penting untuk menguasai pengkajian proses keperawatan berbasis spiritual dalam rangka peningkatan mutu dan layanan sehingga dapat mempercepat proses pengkajian melalui data yang telah di dapat dan menentukan diagnosa, rencana, implementasi, evaluasi, dan dokumentasi secara lengkap dan relevan.
\end{abstract}

Kata Kunci : peran perawat, tahapan pengkajian, proses keperawatan, spiritual.

\begin{abstract}
Background: The nursing process is inseparable from the role of nurses in carrying out their duties and responsibilities in providing health services to patients. One of them is conducting a study. This is important because the assessment in the nursing process is a document that records the actions taken by nurses on patients. Purpose : To identify the initial steps in making an assessment, nursing diagnosis, nursing care plan, implementation, evaluation, documentation of spiritual nursing care. Method: the method used is a literature review or a comparison or analysis of one journal with other journals from various sources such as journal references, textbooks and e-books. Results: The result is that a nurse is able to carry out the stages of assessment in the nursing process both spiritually appropriately in accordance with standard operating procedures and data found by nurses. Conclusion : As a nurse it is very important to master the assessment of spiritual-based nursing processes in order to improve quality and service so that it can accelerate the assessment process through data that has been obtained and determine diagnoses, plans, implementations, evaluations, and documentation in a complete and relevant manner.
\end{abstract}

Keywords : role of nurses, stages of assessment, nursing process, spiritual. 


\section{Latar Belakang}

Memberikan layanan kesehatan yang layak dan baik kepada masyarakat merupakan suatu tanggung jawab dari perawat maupun tim medis lainnya baik di klinik, puskesmas, maupun rumah sakit. Penting bagi perawat untuk memahami konsep yang mendasari kesehatan spiritual. Spiritualitas merupakan suatu konsep yang unik pada masing-masing individu yang akhir-akhir ini banyak dipertimbangkan dalam proses perawatan. Hal inididasari asumsi bahwa aspek spiritual berkontribusi dalam menentukan kebahagiaan hidup seseorang. Dengan demikian, perawat juga perlu memahami keterkaitandimensi fisik, psikologis, dan kebudayaan dengan aspek spiritual dalam upaya perbaikan kualitas hidup pasien (Hidayat, 2004).

Pemenuhan kebutuhan spiritual pasien merupakan bagian dari peran dan fungsi perawat dalam pemberian asuhan keperawatan. Oleh karena itu, diperlukan sebuah metode ilmiah untuk menyelesaikan masalah keperawatan secara sistematis melalui pendekatan proses keperawatan yang diawali dari pengkajian data, penetapan diagnosa, perencanaan, implementasi, dan evaluasi dengan mengikutsertakan aspek spiritual. Asuhan keperawatan berbasis spiritual dapat diidentifikasi pada masing-masing tahapan berikut (Hamid, 2008)

\section{Pengkajian}

Pengkajian aspek spiritual membutuhkan hubungan interpersonal yang baik antara perawat dengan pasien. Oleh karena itu, pengkajian sebaiknya dilakukan setelah perawat dapat membentuk hubungan yang baik dengan pasien atau dengan orang terdekat pasien. Pengkajian asuhan keperawatan spiritual yang perlu dilakukan meliputi:

a. Pengkajian data subjektif

Pedoman pengkajian data subjektif dalam asuhan keperawatan spiritual secara umum mencakup konsep tentang ketuhanan, sumber kekuatan dan harapan, praktik agama dan ritual, serta hubungan antara keyakinan spiritual dan kondisi kesehatan.

b. Pengkajian data objektif

Pengkajian data objektif dilakukan melalui pengkajian klinis yang meliputi pengkajian afeksi dan sikap, perilaku, verbalisasi, hubungan interpersonal, dan lingkungan. Pengkajian data objektif umumnya dilakukan melalui observasi secara langsung.

2. Diagnosa Keperawatan 
Diagnosa keperawatan yang berkaitan dengan masalah spiritual menurut North American Nursing Diagnosis Association (NANDA) adalah distresspiritual yang dapat diidentifikasi sebagai gangguan kemampuan dalam mengintegrasikan arti dan tujuan hidup seseorang yang dihubungkan dengan diri, orang lain, seni, musik, alam, atau kekuatan yang lebih besar dari dirinya (NANDA, 2006).

Batasan karakteristik diagnosa keperawatan spiritual secara spesifik dapat dijabarkan sebagai berikut (NANDA, 2006):

a. Berhubungan dengan diri, meliputi kemampuan mengekspresikan kurang dalam harapan, tujuan hidup, kedamaian, penerimaan, cinta, memaafkan diri, keberanian, marah, serta rasa bersalah.

b. Berhubungan dengan orang lain, meliputi upaya penolakandalam berinteraksi dengan pemimpin agama, menolak berinteraksi dengan teman dan keluarga, mengungkapkan terpisah dari sistem dukungan, serta merasa terasing. c. Berhubungan dengan seni, musik, dan alam, meliputi ketidakmampuan mengekspresikan kondisi kreatif serta ketidaktertarikan terhadap alasan bacaan agama.

d. Berhubungan dengan kekuatan yang melebihi dirinya, meliputi ketidakmampuan beribadah, tidak mampu berpartisipasi dalam aktivitas agama, mengekspresikan ditinggalkan atau marah kepada Tuhan, tidak mampu untuk mengalami transenden, perubahan mendadak dalam praktek keagamaan, tidak mampu introspeksi, serta mengalami penderitaan tanpa harapan.

Perubahan-perubahan karakteristik spiritual pada pasien dapat berimplikasi pada berbagai kondisi kesehatan. Keadaan tersebut dapat didiagnosis sebagai pengasingan diri, kesendirian atau pengasingan sosial, cemas, deprivasi atau kurang dalam sosiokultural, kematian dan sekarat, nyeri, perubahan hidup, dan penyakit kronis (NANDA, 2006).

3. Perencanaan

Setelah diagnosa keperawatan dan faktor yang berhubungan teridentifikasi, 
selanjutnya perawat dan pasien menyusun kriteria hasil dan rencana intervensi. Tujuan asuhan keperawatan pada pasien dengan distres spiritual difokuskan pada pembentukan lingkungan yang mendukung praktek keagamaan dan kepercayaan yang biasanya dilakukan. Tujuan ditetapkan secara individual dengan mempertimbangkan riwayat pasien, area berisiko, dan tanda-tanda disfungsi, serta data objektif yang relevan. Menurut Kozier et al. (2010), perencanaan pada pasien dengan distres spiritual dirancang untuk memenuhi kebutuhan spiritual pasien dengan membantu pasien memenuhi kewajiban agamanya, membantu pasien menggunakan sumber dari dalam dirinya dengan cara yang lebih efektif untuk mengatasi situasi yang sedang dialami, membantu pasien mempertahankan atau membina hubungan personal yang dinamik dengan Maha Pencipta ketika sedang menghadapi peristiwa yang kurang menyenangkan, membantu pasien mencari arti keberadaannya dan situasi yang sedang dihadapinya, meningkatkan perasaan penuh harapan, dan memberikan sumber spiritual atau cara lain yang relevan.

\section{Implementasi}

Pada tahap implementasi, perawat menerapkan rencana intervensi dengan melakukan prinsip-prinsip kegiatan asuhan keperawatan dengan memeriksa keyakinan spiritual pribadi perawat, memfokuskan perhatian pada persepsi pasien terhadap kebutuhan spiritualnya, menghindari anggapan pasien tidak mempunyai kebutuhan spiritual, memahami pesan non-verbal tentang kebutuhan spiritual pasien, merespon secara singkat, spesifik, dan aktual, mendengarkan secara aktif dan menunjukkan empati terhadap masalah pasien, membantu memfasilitasi pasien agar dapat memenuhi kewajiban agama, serta memberitahu pelayanan spiritual yang tersedia di rumah sakit (Hawari, 2002).

Pada tahap implementasi, perawat juga harus mempertimbangkan 10 butir kebutuhan dasar spiritual manusia yang meliputi kebutuhan akan kepercayaan dasar, kebutuhan akan makna dan tujuan hidup, kebutuhan akan komitmen peribadatan dan hubungannya dengan keseharian, kebutuhan akan pengisian keimanan secara teratur mengadakan hubungan dengan Tuhan, kebutuhan akan bebas dari rasa bersalah dan dosa, kebutuhan akan penerimaan diri dan 
harga diri, kebutuhan akan rasa aman terjamin dan keselamatan terhadap harapan masa depan, kebutuhan akan dicapainya derajat dan martabat yang makin tinggi sebagai pribadi yang utuh, kebutuhan akan terpeliharanya interaksi dengan alam dan sesama manusia, serta kebutuhan akan kehidupan bermasyarakat yang penuh dengan nilainilai religius (Hawari, 2002).

Perawat berperan
komunikator perantarabila pasien
menginginkan untuk bertemu dengan
petugas rohaniawan atau bila menurut
perawat memerlukan bantuan
rohaniawan dalam mengatasi masalah
spiritualnya. Menurut Bulechek et al.
(2013) dalam Nursing Interventions Classification (NIC), intervensi keperawatan dari diagnose distress spiritual salah satunya adalah spiritual support dengan membantu pasien mencapai keadaan seimbang dan merasa berhubungan dengan kekuatan Maha Besar.

\section{Evaluasi}

Untuk mengetahui apakah pasien telah mencapai kriteria hasil yang ditetapkan pada fase perencanaan, perawat perlu mengumpulkan data terkait dengan pencapaian tujuan asuhan keperawatan spiritual. Tujuan asuhan keperawatan spiritual tercapai apabila secara umum pasien:

a. Mampu beristirahat dengan tenang

b. Mengekspresikan rasa damai berhubungan dengan Tuhan

c. Menunjukkan hubungan yang hangat dan terbuka dengan pemuka agama

d. Mengekspresikan arti positif terhadap situasi dan keberadaannya

e. Menunjukkan afeksi positif, tanpa rasa bersalah, dan kecemasan.

\section{Tujuan}

1. Tujuan umum

Untuk mengidentifikasi langkah awal dalam membuat suatu pengkajian, diagnosa keperawatan, rencana asuhan keperawatan, implementasi, evaluasi, dokumentasi asuhan keperawatan berbasis spiritual.

2. Tujuan khusus

Untuk mengetahui :

a. Pengertian pengkajian dalam proses keperawatan

b. Pengumpulan data dalam pengkajian

c. Klasifikasi data

d. Perumusan masalah 


\section{Metode}

Metode yang digunakan adalah metode literatur review ataupun suatu perbandingan dan analisis antara satu jurnal dengan jurnal lainnya dari berbagai sumber seperti referensi jurnal, buku teks dan e-book. Penulisan jurnal ini melakukan metode perbandingan dan isi yang akan di bandingkan berhubungan dengan pengkajian dalam proses keperawatan.

\section{Hasil}

Pengkajian dalam hal ini adalah pengkajian spiritual yang seharusnya dilakukan oleh perawat dalam menata laksana asuhan keperawatan. Pengkajian spiritual tidak diidentikasi akibat kurangnya pengetahuan dari perawat, kebijakan rumah sakit, dan keterbatasan dalam format pengkajian spiritual.
1. Pengkajian keperawatan spiritual belum dilaksanakan secara maksimal oleh perawat pelaksana

2. Pengkajian keperawatan spiritual tidak ditanyakan kepada pasien pada saat wawancara

3. Pengkajian spiritual hanya dilakukan oleh ulama
4. Pengkajian keperawatan spiritual dianjurkan untuk dilakukan oleh perawat pelaksana namun tidak dilaksanakan sesuai standar

5. Pengkajian spiritual tidak didokumentasikan dan kurang pengetahuan tentang hal-hal yang harus dikaji pada masalah spiritual.

Diagnosa keperawatan spiritual belum ditegakkan dan didokumentasikan secara maksimal.

1. Diagnosa keperawatan spiritual ditegakkan pada pasien-pasien tertentu dan tidak maksimal

2. Diagnosa keperawatan spiritual belum ditegakkan oleh perawat

Intervensi keperawatan spiritual belum maksimal dan keterbatasan pengetahuan dari perawat.

1. Intervensi keperawatan spiritual dilakukan melalui kolaborasi, namun belum maksimal

2. Intervensi keperawatan spiritual tidak berdasarkan masalah (diagnosa) spiritual, namun bersifat umum untuk semua pasien

3. Keterbatasan pengetahuan intervensi keperawatan spiritual bagi perawat pelaksana 
Implementasi keperawatan spiritual sudah dilaksanakan namun belum menyeluruh baik dari aspek psikomotor maupun dokumentasi.

1. Implementasi keperawatan spiritual belum sepenuhnya dilaksanakan oleh perawat pelaksana

2. Instansi rumah sakit menugaskan ustadz dalam penanganan spiritual

Evaluasi keperawatan spiritual tidak dilakukan oleh petugas dan perawat.

1. Perawat pelaksana kurang memahami evaluasi keperawatan spiritual

2. Evaluasi yang dilakukan hanya pada masalah fisik dan psikologis.

\section{Pembahasan}

Penting pada pengkajian perawat untuk lebih dulu mempertimbangkan reaksi klien. Ketika klien dan perawat berinteraksi, perawat menanyakan pertanyaan yang relevan untuk mengumpulkan lebih banyak data. Hal ini mengharuskan praktik bagi perawat pemula untuk menjadi lebih terampil. Jika perawat berhenti secara dini dalam mengajukan pertanyaan, data dasar tidak lengkap dan konklusi yang di ambil, yang dibuat dalam format diagnosa keperawatan menjadi tidak akurat. Segala kesimpulan tentang klien atau tentang perilaku perawat sendiri dipisahkan dari data aktual (Potter \& Perry, 2005).

Perawat mengumpulkan data yang bersifat deskriptif, singkat, dan lengkap. Pengkajian tidak mencakup kesimpulan atau pernyataan interpretatif yang tidak didukung oleh data. Pengumpulan data yang tidak akurat, tidak lengkap, atau tidak sesuai mengarah pada identifikasi kebutuhan perawatan klien yang tidak tepat dan akibatnya diagnosa keperawatan yang dibuat menjadi tidak akurat, tidak lengkap, atau tidak sesuai. Data yang tidak akurat terjadi bila perawat tidak berhasil untuk mengumpulkan informasi yang relevan dengan area spesifik atau jika perawat tidak teratur atau tidak terampil dalam teknik pengkajian.

\section{Penutup}

\section{Kesimpulan}

Sebagai seorang perawat sangatlah penting untuk menguasai pengkajian proses keperawatan berbasis spiritual dalam rangka peningkatan mutu dan layanan sehingga dapat mempercepat proses pengkajian melalui data yang telah di dapat dan menentukan diagnosa, rencana, 
implementasi, evaluasi, dan dokumentasi secara lengkap dan relevan.

\section{Saran}

Peran perawat dalam menerapkan pengkajian proses keperawatan di rumah sakit hendaknya tidak hanya terfokus pada data fisik dan psikologis, tetapi juga pada spiritual sehingga menumbuhkan rasa kenyamanan pada pasien yang menginginkannya.

\section{Daftar Pustaka}

Asmadi, (2008). Konsep Dasar Keperawatan. Jakarta : EGC

Bulechek, G.M., Butcher, H.K., Dochterman, J.M., Wagner, C.M. (2013) Nursing Interventions Classification (NIC), Sixth Edition. St. Louis: Elsevier Mosby. Availableat https://www.elsevier.com/books/n ursing-interventionsclassification-nic/

Bumulo, M. I., Bidjuni, H., \& Bawotong, J. (2017). Pengaruh Manajemen Model Asuhan Keperawatan Profesional Tim terhadap Kualitas Pelayanan Keperawatan di Bangsal Pria RSUD Datoe Binangkang Kabupaten Bolang Mongondow.
e-Jurnal Keperawatan (e-Kp), 5, 1-6.

Damhudi, dedi, dkk. Efektivitas metode NIHSS dan ESS dalam membuat diagnosa keperawatan aktual pada pasien stroke berat fase akut. Vol (15). No (1). Hal 7-12.

Hamid, A.Y.S. (2008) Buku Ajar Aspek Spiritual dalam Keperawatan. Jakarta : Widya Medika.

Hawari, D. (2002). Dimensi Religi dalam Praktik Psikiatri dan Psikologis. Jakarta : Fakultas Kedokteran Universitas Indonesia. Henderson, C., Jones, K. (2006). Buku Ajar Konsep Kebidanan. Jakarta : EGC.

Hidayat, A.A. (2004). Pengantar Konsep Dasar Keperawatan. Jakarta : Salemba Medika

Kozier, B., Erb, G., Berman, Snyder, S. (2010). Buku Ajar Fundamental Keperawatan : Konsep, Proses, \& Praktik, Volume 2, Edisi 7. Jakarta : EGC.

NANDA. (2006). Panduan Diagnosa Keperawatan North American Nursing Diagnosis Association (NANDA): Definisi dan Klasifikasi. Editor: Budi Sentosa. Jakarta : Prima Medika. 
Potter dan Perry. (2005). .Fundamental Keperawatan Konsep Proses dan Praktik,Volume 1, Edisi 4. Jakarta : EGC

Rieg, L.S., Mason, C.H., Preston, K. (2006) Spiritual care: practical guidelines for rehabilitation nurses. Rehabilitation Nursing Journal. 31(6):249-256. Available at

https://www.ncbi.nlm.nih.gov/pub $\underline{\text { med/17133926 }}$

Saharuddin, dkk. (2018). Penerapan model pelayanan keperawatan berbasis spiritual ditinjau dari aspek proses asuhan keperawatan spiritual di rumah sakit islam Faisal Makassar. Vol (10). No (1). Simamora, R. H. (2008). Peran Manajer Perawat Dalam Pembinaan Etika Perawat Pelaksana Dalam Peningkatan Kualitas Asuhan Keperawatan. IKESMA

Simamora, R. H. (2009). Dokumentasi Proses Keperawatan. Jember. University Press

Simamora, R. H. (2010). Komunikasi Dalam Keperawatan. Jember: University Press

Tuhareal, N.A. dkk. (2017). Sistem komputerisasi untuk pencatatan laporan asuhan keperawatan untuk mahasiswa ilmu keperawatan. Vol (4). N0 (4). 